\title{
In Memoriam: \\ Christy G. Turner II \\ (November 28, 1933 - July 27, 2013) \\ Personal reflections on his legacy in dental anthropology and beyond
}

I was an undergraduate at Arizona State University in 1966 when Christy was brought into the Department of Anthropology. I took three of his courses as an undergraduate: World Prehistory, Southwest Archaeology: Anasazi, and Physical Anthropology (Human Biology). I mention this because his courses were both a challenge and an inspiration. He was the most charismatic professor I had encountered and when he discovered I was a fairly good student, he slowly brought me into the 'physical anthropology' fold, redirecting me away for my original goal of becoming a professional archaeologist. He talked Charles Woolf into offering me a graduate fellowship in genetics and that dictated my direction in graduate school, the genetic analysis of dental morphological traits. In retrospect, I got in on the ground floor of something that would eventually become a very significant edifice in the field of physical anthropology and it was Christy who laid much of the foundation.

Christy was all that one could ask for in a mentor. He was encouraging yet demanding. When I was thinking about taking a few extra courses as a graduate student, he said something I tell my students to this day: "When you finish your PhD, you don't stop learning..........that's when you start learning." That was more prophetic than I knew at the time. That stimulated me to finish my PhD in expeditious fashion without taking a lot of extra coursework. When I defended my dissertation in the summer of 1973, I was Christy's first PhD in physical anthropology. Through his Wisconsin contacts, he helped me secure a job at the University of Alaska Fairbanks. Although Alaska was definitely not my first choice to start my career, the doors of academia were closing at that time so I took the job and eventually appreciated the opportunities it provided. As his dissertation was titled The Dentition of Arctic Peoples he could not have been happier about where I landed, despite my initial reluctance to go from the fire (Arizona) to the icebox (Alaska).

After leaving for Alaska, Christy and I always stayed in close touch and collaborated on many articles. Neither of us ever thought much about writing books, but in the 1990s, at Gabe Lasker's invitation, we wrote a book published by Cambridge University Press entitled The Anthropology of Modern Human Teeth: Dental Morphology and Its Variation in Recent Human Populations (1997). When the book drew near completion, we were talking about titles. I originally suggested only the second half of the title above. It was Christy who thought 'The Anthropology of Modern Human Teeth' had more panache, and was often the case, he was absolutely right. While Christy was not the 'father' of dental anthropology, an honor that should go to Albert A. Dahlberg and P.O. Pedersen, he was definitely the major driving force in the field for the past $40+$ years.

In 2010, Joel Irish (PhD, ASU, 1993) and I organized a symposium in Christy's honor at the AAPA meeting in Albuquerque, New Mexico. We had no trouble finding contributors to a full symposium and even had to pull our own papers to keep the number to the maximum allowed of 14 . After the symposium, we submitted a book proposal to Cambridge for a festschrift volume entitled Anthropological Perspectives on Tooth Morphology: Genetics, Evolution, Variation. Of the 21 papers in the final volume, six authors were former students of his. Thankfully, the volume appeared in March, 2013, so Christy had time to appreciate how others in dental anthropology viewed his monumental contributions. The second chapter, written by Christy, provides an excellent summary of his academic and professional life, along with acknowledging the many students he mentored during his decades of service at ASU.

The traits that best describe Christy are charismatic, driven, productive, imaginative, and far

sighted. While others described dental morphological traits, Christy could see their potential in asking questions of population origins and relationships. He travelled the world over and made dental observations on over 30,000 human skeletons. He knew the insides of about every museum in North America and many in South America, Siberia, North Asia, Southeast Asia, and Europe. But he didn't just de- 
scribe teeth; he developed the methods that are the foundations of modern dental comparative studies (The Arizona State University Dental Anthropology System). Beyond methods, he developed models that addressed long-standing historical issues, including his three-wave model for the peopling of the Americas, and the dental division between North Asians (Sinodonts) and Southeast Asians (Sundadonts). While his ideas may or may not prove to be correct in the long run, he developed models that other researchers had to consider, even if they disagreed with him.

On another front, Christy started what was basically a new field of inquiry when he examined what was presumed to be a secondary burial from Polacca Wash, a site near the abandoned Hopi village of Awatovi. Although his interest, per usual, was in making dental observations, he thought this collection of broken and burned bones could hardly be a secondary burial. After a detailed analysis of cut marks, anvil abrasions, burned bone, etc., he wrote his first paper on Southwest cannibalism entitled "A Massacre at Hopi," co-authored with one of his graduate students, Nancy Tucker Morris. After examining this series, he ran down many more skeletal collections from the Anasazi region that could most parsimoniously be explained by cannibalism. Needless to say, this was not a popular view and he was attacked by Native Americans and professional colleagues who took issue with his interpretation. The culmination of this work came in the volume Man Corn: Cannibalism and Violence in the Prehistoric American Southwest (1999), co-authored with Jacqueline, his wife, companion, and collaborator. Always thorough to an admirable fault, he went to central Mexico and examined skeletal series where cannibalism was widely acknowledged. His view was that if you disagreed with his taphonomic signature for cannibalism, provide an alternative explanation for bones that had been bashed, burned, and butchered. Christy had file after file of papers written on the subject and he never felt anyone seriously dented his interpretation of cannibalism, which he always clearly separated from evidence of just violence.

Christy was definitely the hardest working scholar I have ever known. Even with failing health and eyesight greatly diminished by macular degeneration, he just completed another book for Cambridge University Press entitled Animal Teeth and Human Tools: A Taphonomic Odyssey in Ice Age Siberia. How he could write and edit a 500 page volume with dozens of tables and photos with all of his physical limitations astounds me to this day. He had a great career and had already made significant marks in dental anthropology and the taphonomy of human cannibalism but he kept pressing on. Thankfully, he finished all the edits and copy proofing of the galleys this past spring and the volume is now in press. Sadly, he will not be around to see this work in book form.

When I was a graduate student, Christy told me his academic idols were William Healy Dall, Franz Boas, and Aleš Hrdlička, who published, respectively 1500, 800, and 600 papers and books. I know Christy's vita is over 50 pages long but I'm not sure if he matched those gentlemen..........of this I am sure though, he gave it 'the old college try.'

For over 40 years, Christy and I (and our families) remained close; we stayed with the Turners on Campo Alegre many times and they stayed with us when they came to Alaska. I could go on and on about the many things we did, crazy and otherwise, but I will save those for private conversations, preferably at a bar during annual meetings of the American Association of Physical Anthropologists. His legacy is substantial, his footprint is large........he will be missed and remembered by his daughters and grandchildren along with countless former students and colleagues because he was a 'unique character,' one whose time on earth made the world a more interesting place.

\author{
G. Richard Scott \\ Department of Anthropology \\ University of Nevada Reno \\ Reno NV 89557
}

